\title{
THE EFFECTS OF THE ZINC SUPPLEMENTATION AND WEIGHT TRAININGS ON THE TESTOSTERONE LEVELS
}

\author{
V. Çınar ${ }^{1}$, cinarvedat@hotmail.com, ORCID: 0000-0003-4883-3995, \\ L.G. Talaghir', gtalaghir@ugal.ro, ORCID: 0000-0002-3133-9192, \\ T. Akbulut ${ }^{1}$, akbuluttaner23@gmail.com, ORCID: 0000-0003-2500-1117, \\ M. Turgut ${ }^{3}$, minetrgt@gmail.com, ORCID: 0000-0002-8556-3114, \\ M. Sarıkaya4, mucahit.sarikaya@hotmail.com \\ ${ }^{1}$ Firat University, Elazig, Turkey, \\ ${ }^{2}$ Dunărea de Jos University, Galati, Romania, \\ ${ }^{3}$ Bartin University, Bartin, Turkey, \\ ${ }^{4}$ Van Yuzunciyıl University, Van, Turkey
}

\begin{abstract}
Aim. The purpose of this study, it has been aimed to examine the effects of zinc supplementation applied with weight trainings on the testosterone levels in sedentary individuals and athletes. Materials and Methods. As methods of work it was selected 40 male, 20 sedentary male and 20 male who do physical exercises regularly, participated in the study. The participants are divided equally into 4 groups. The groups are constituted in that way: $1^{\text {st }}$ Group: Control Group (S), $2^{\text {nd }}$ Group: Sedentary Group which is supplied with Zinc (Z), $3^{\text {rd }}$ Group: Training Group which is supplied with Zinc (ZT) and $4^{\text {th }}$ Group: Athletes' Group who performs the weight training (T). The total testosterone and free testosterone values of the participants were measured from the blood samples which were drawn from the participants at the beginning and at the end of the 6-week training period. Results. Like results, has been asserted that the total and free testosterone values of the groups which are supplied with Zinc and perform weight training have increased depending on training and supplementation. Conclusion. In conclusion consequently it has been determined that 6-week zinc supplementation and weight training increase the testosterone levels. Accordingly, it may be said that this implementation contributes to the performance.
\end{abstract}

Keywords: exercise, zinc supplementation, testosterone.

Introduction. Zinc is one of the significant and fundamental minerals for organisms. Zinc is the second most common trace element in human body after iron. It does not accumulate excessively in tissues though it is consistently taken through nutriment [12]. Although zinc is found in small quantities in human body, it takes on tasks with protein in every organ. Zinc has importance particularly in growth and development, reproduction and immune system [3].

Total zinc content in body is approximately 1,5 gram in women while it is 2,5 gram in men [18]. Zinc moves in and out of the cells through transport proteins. These transport proteins takes zinc and protects cells from zinc toxicity and enables sufficient amount of zinc to be obtained. Common zinc transporting proteins are ZIP proteins, ZnT4 proteins and metallothionein [19].

While testosterone is produced by main testis in male, its primary source is the adrenal gland and ovaries in female. In male, approximately $7 \mathrm{mg}$ testosterone is produced daily under the control of hormonal feedback [23]. Although tes- tosterone is swung regularly in young men, it has been asserted the testosterone levels decrease with increasing age in male [17].

Testosterone is a steroid-type hormone produced out of cholesterol. Steroid hormones that can be produced in adrenal glands, gonads and placenta play a significant role in the growth, development and maturation of the brain [5, 20].

In conclusion, it has been demonstrated that testosterone has regulatory effects in sexuality, aggression, sleeping control, cognitive functions, visual spatial skills, endurance and mood in male $[14,17]$. It is known that androgens which have growth and virilization stimulating effect are widely used illegally in order to increase the muscle structure and accordingly the performance of the athletes because of their anabolic effects occurring when its primary therapeutics usage forms the therapy of hormone replacement [2]. However, its dosage used in order to develop muscles and improve performance of the athletes may be higher than required dosage [10].

Testosterone is a hormone that has effects on 
the skeletal muscle. The most prominent effect of testosterone is the increase in muscle mass and glycogens concentration. In a study conducted on that issue, it has been set forth that short term high-intensity tiring training enables increase in total testosterone levels of the athletes and this increase is observed to continue more distinctively and significantly in cyclists than the football players. That demonstrates that cyclists may be affected by the maximal resistance exercises [1].

Similarly, in the study of [22], the male and female subjects perform 6 sets squat exercises for 10 times in order to identify the muscle androgenous and glucocorticoide receptors of the acute resistance exercises. While free testosterone levels increase significantly in both genders through exercises, total testosterone levels increase in only male subjects. The [8] subjects 624 voluntary male ranging in age from 25 to 85 to a short term highly heavy exercises in cycle ergometer and state that the serum testosterone levels of the participants are not affected.

In parallel with this information, in this study it has been aimed to examine the effects of 6-week zinc supplementation applied with weight trainings on the free and total testosterone levels. The paper is equal contribution of all authors.

Materials and Methods. The Subjects: 40 healthy male subjects ranging in age from 18 to 22 participate in the study. The subjects are equally divided into 4 groups. The pre-test and post-test model is used. The population of the study comprises of the students of Adiyaman University who do physical exercises actively in different branches and the ones who do not do sports. All of the subjects stay in the dormitory of Adiyaman University and are liable to the same diet.

$1^{\text {st }}$ Group: Control Group (S)

$2^{\text {nd }}$ Group: Sedentary Gorup which is only supplied with Zinc (Z)

$3^{\text {rd }}$ Group: Training Group which is supplied with Zinc (ZT)

$4^{\text {th }}$ Group: Athletes' Group who performs the weight training $(\mathrm{T})$

The $2^{\text {nd }}$ and $3^{\text {rd }}$ group are supplied with zinc $(2,5-3 \mathrm{mg} / \mathrm{kg} /$ day $)$ in addition to the normal diet for 6 weeks. In addition, the $3^{\text {rd }}$ and $4^{\text {th }}$ group perform weight training for 90-120 minutes throughout 6 weeks and the $1^{\text {st }}$ group, the control group, are not given zinc supplementation and do not perform weight trainings.

Examination of the Testosterone. The blood samples are centrifuged at $3000 \mathrm{rpm}^{3}$ for $10 \mathrm{mi}$ -

\section{и силовых тренировок на уровень тестостерона}

nutes and the blood plasma fractionation is done. The measurement of the plasma parameters is carried out at the Biochemistry laboratory of Özel Işı1 Kardiyoloji Dalı Merkezi (Private Işı1 Cardiology Center) which operates in Diyarbakır. The analysis of Testosterone level is done through the Enzymatic Colometric method by using the scientific brand BT3000 biochemistry auto analyzer.

The Statistical Analyses. Variance analysis is used to identify the differences between the values of the groups obtained through measurements; and the Duncan's Multiple Range Test is used to determine in which groups differentiations are observed. The comparison of the groups is done through t-test in order to identify the differentiations between the values of the groups obtained through measurements the statistical analyses are conducted via SPSS 22.0.

Results. When the bodyweight values given at (Table 1) is examined, it has not been found any differences between the pre-test and post-test values of the $1^{\text {st }}$ group $(p>0.05)$. It is identified statistically significant differences between the pre-test and post-test values of the $2 \mathrm{nd}, 3 \mathrm{rd}$ and 4 th groups. It has been determined that zinc supplementation and weight training enables individuals to lose weight $(\mathrm{p}<0.05)$. It is observed differences between the groups when the weight loss of the groups is compared with the control group and other groups $(\mathrm{p}<0.05)$.

The total and free testosterone values of the groups are given at (Table 2). As the total testosterone values are considered, it is determined that values of both training and supplementation groups increase after the implementation $(p<0.05)$. When the pre-test and post-test values are examined, it has been identified statistically significant differences in zinc supplementation, exercise, and zinc supplementation + exercise groups $(\mathrm{p}<0.05)$. Considering the free testosterone values, it has been observed differences between the pre-test and post-test values and also the values increase at the end of the implementation $(\mathrm{p}<0.05)$.

Discussion. In this study which aims to examine the effects of 6-week zinc supplementation applied with weight trainings 4 times a week on the free and total testosterone levels in sedentary and athletes, the total testosterone and free testosterone values of the participants were measured from the blood samples which were drawn from the participants at the beginning and at the end of the 6-week training period. When 


\section{Спортивная тренировка}

these measurements are compared, it is identified that zinc supplementation applied with weight trainings create positive changes in both free and total testosterone levels. It is confirmed that these changes are seen in both groups supplied with zinc and training and zinc supplementation + training groups.

In a study conducted on a similar issue, it is asserted that ZMA (a synthesis of zinc, magnesium and B6 vitamin) which is thought to increase the testosterone levels and given to the individuals doing regular exercises for 8 weeks have not created any differences in serum free and total testosterone values of the participants [9]. It is thought different findings may result from implementing different training programs and usage of a combination of supplementation. In another study in which it has been obtained findings parallel to ours, [15] examine the effect of 4-week zinc and selenium supplementation on the post exhaustion exercise testosterone and plasma lactate levels in cyclists. In conclusion, it is determined that total testosterone is higher in the group supplied with zinc than the values of the groups supplied with selenium; and free testosterone levels are higher in the zinc group than the values of the other groups. They argue that zinc and selenium supplementation do not create any change in rested values at the end of 4 weeks. The [6] has examined the effect of 4-week zinc supplementation on the thyroid and testosterone levels in wrestlers. At the end of the study, it has been determined 4-week zinc supplementation ( $3 \mathrm{mg} / \mathrm{kg} /$ day) generates significant increases in rested total and free testosterone levels. In another study in which similar findings have been obtained, [7] has examined the changes zinc supplementation applied with tiring cycling ergometer exercise create in the thyroid and testosterone levels of the sedentary individuals. At the end of 4 weeks, it has been found out the zinc sulphate supplementation $(3 \mathrm{mg} / \mathrm{kg} /$ day $)$ increases the thyroid hormone and free and total testosterone levels in sedentaries after exercises.

In the study which examines the effect of doing exercises on the testosterone, [16] have asserted that high-intensity endurance exercises done in cycling ergometer create significant increases in the levels of testosterone. In another study which has set forth doing exercises do not affect the testosterone levels, [5] have examined the physical, muscular and endocrine responses arisen 24 hours after the acute weight and maximal speed exercises. Consequently, it has not been determined any changes in creatine kinase, testosterone, cortisol and muscle injury considering the blood samples drawn from the participants 24 hours after the acute and high-intensity exercises done. It is thought that these findings confronting with our results may arise from implementing acute exercises. In a study conducted on subject animals, [24] have examined

The Age, Height, Weight and Fat Values of the Research Groups

Table 1

\begin{tabular}{|l|l|c|c|c|c|}
\hline \multicolumn{1}{|c|}{ Values } & \multicolumn{1}{|c|}{ Measurement } & 1st Group (Cont) & 2nd Group (Zn) & 3rd Group (Tra + Zn) & 4th Group Training \\
\hline Age (year) & I. Measurement & $20.04 \pm 2.20 \mathrm{x}$ & $21.02 \pm 3.10 \mathrm{x}$ & $20.89 \pm 2.06 \mathrm{x}$ & $20.44 \pm 3.02 \mathrm{x}$ \\
\hline Height (cm) & II. Measurement & $174.52 \pm 7.56 \mathrm{x}$ & $175.40 \pm 8.25 \mathrm{x}$ & $175.08 \pm 7.15 \mathrm{x}$ & $176.02 \pm 7.20 \mathrm{x}$ \\
\hline Weight (kg) & I. Pre test & $76.60 \pm 5.42 \mathrm{ax}$ & $75.22 \pm 5.70 \mathrm{ax}$ & $75.84 \pm 5.92 \mathrm{ax}$ & $74.63 \pm 5.86 \mathrm{ax}$ \\
& II. Posttest & $75.32 \pm 6.90 \mathrm{ay}$ & $77.71 \pm 5.57 \mathrm{bx}$ & $78.22 \pm 6.12 \mathrm{bx}$ & $77.42 \pm 6.08 \mathrm{bx}$ \\
\hline
\end{tabular}

Note: $\mathrm{a}, \mathrm{b}$; the differences in measurements that carry different letters at the same column are important $(\mathrm{p}<0.05) ; \mathrm{x}, \mathrm{y}, \mathrm{z}$; the differences between the groups that carry different letters at the same line are important $(\mathrm{p}<0.05)$. I. Measurement: Pre-Supplementation (Pre Test). II. Measurement: Post-Supplementation (Post Test).

Total and Free Testosterone Values of the Research Groups

Table 2

\begin{tabular}{|l|l|c|c|c|c|}
\hline \multicolumn{1}{|c|}{ Values } & Measurements & 1st Group (Cont) & 2nd Group (Zn) & 3rd Group (Tra + Zn) & 4th Group Training \\
\hline Total & I. Pretest & $596,20 \pm 52 \mathrm{ax}$ & $604,30 \pm 0.87 \mathrm{ax}$ & $612,60 \pm 0.96 \mathrm{ax}$ & $616,50 \pm 0.90 \mathrm{ax}$ \\
$\begin{array}{l}\text { Testosterone } \\
\text { (uIU/mL) }\end{array}$ & II. Post test & $605,40 \pm 0.88 \mathrm{ax}$ & $638,60 \pm 0.74 \mathrm{by}$ & $654,20 \pm 0.92 \mathrm{by}$ & $658,30 \pm 0.92 \mathrm{by}$ \\
\hline Free & & & & & \\
Testosterone & II. Pre test & $14,8 \pm 3.76 \mathrm{ax}$ & $15,7 \pm 3.50 \mathrm{ax}$ & $16,8 \pm 4.48 \mathrm{ax}$ & $16,6 \pm 3.44 \mathrm{ax}$ \\
\hline
\end{tabular}

Note: $\mathrm{a}, \mathrm{b}$; the differences in measurements that carry different letters at the same column are important $(\mathrm{p}<0.05) ; \mathrm{x}, \mathrm{y}, \mathrm{z}$; the differences between the groups that carry different letters at the same line are important $(\mathrm{p}<0.05)$. I. Measurement: Pre-Supplementation (Pre Test). II. Measurement: Post-Supplementation (Post Test). 
the effects of regular exercises on the blood glucose and testosterone in diabetic rats. They have determined that moderate exercises implemented for 9 weeks decrease the blood glucose and enhance the testosterone levels. In a study conducted on human subjects, [21] have studied the serum anabolic and catabolic effects of the acute exercises performed close to the anaerobic threshold in antrene and sedentary young males. In conclusion, the cortisol levels of both sedentary and athlete groups decrease below the basal level in 24 hours following the exercise. Additionally, anabolic hormones (testosterone, growth hormone and insulin-like growth factor-1) have increased significantly in both groups but particularly in the antrene group. In a similar study, it has been determined that short-term highintensity tiring exercise enables total testosterone levels of the athletes to increase considerably [1]. Similarly, [13] has examined the serum adiponectin and testosterone concentration of 12-week endurance training in young obese males. 21 obese male participants are divided into two groups as control group and experimental group. At the end of the study, it has been confirmed that endurance training implemented 3 times a week for 12 weeks has increased the serum adiponectin and testosterone concentration. The [11] studied the effect of increased exercises and decreased caloric intake on the testosterone levels. They have ascertained that 12-week aerobic exercise and caloric intake restriction have increased significantly the serum testosterone levels.

Conclusions. As a consequence, 6-week zinc supplementation applied with weight trainings 4 times a week in sedentaries and athletes has increased the free and total testosterone levels significantly. Therefore, it may be said the increment of zinc supplementation in human organism increases the testosterone levels and constitutes positive effects on the physical performance.

\section{References}

1. Cakmakci S. [The Effect of Anaerobic Exercises on Certain Hormone Levels in the Athletes from Different Branches]. Institute of Medical Sciences, [Master's Thesis], Konya 2013, pp. $58-70$.

2. Gümüsel B., Kandilci H.B. [Androgens, Anabolic Steroids and Antiandrogenic Drugs]. Türkiye Klinikleri J Int Med Sci, 2005, vol. 1, no. 35, pp. 112-118.

\section{и силовых тренировок на уровень тестостерона}

3. Güzelcan M.S. [Enrichment of Simit with İron and Zinc and Determination of in Vitro Mineral Bioavailability. Ege University]. Institute of Science and Technology, Master's thesis, İzmir 2009, pp. 112-115.

4. Johnston M., Johnston J., Cook C.J., Costley L., Kilgallon M., Kilduff L.P. [The Effect of Session Order on the Physiological, Neuromuscular, and Endocrine Responses to Maximal Speed and Weight Training Sessions Over a 24-h Period]. J Sci Med Sport, 2017, vol. 20, no. 5, pp. 502-506.

5. Kartalcı Ş., Eşel E. [Psychopharmacologic and Behavioral Effects of Neurosteroids]. Klinik Psikofarmakoloji Bülteni, 2004, vol. 14, pp. 38-49.

6. Kilic M., Baltaci A.K., Gunay M., Gökbel H., Okudan N., Cicioglu I. [The Effect of Exhaustion Exercise on Thyroid Hormones and Testosterone Levels of Elite Athletes Receiving Oral Zinc]. Neuro Endocrinology Letters, 2005, vol. 27, no. 1-2, pp. 247-252.

7. Kilic M. [Effect of Fatiguing Bicycle Exercise on Thyroid Hormone and Testosterone Levels in Sedentary Males Supplemented with Oral Zinc]. Neuro Endocrinology Letters, 2007, vol. 28 , no. 5, pp. 681-685.

8. Koch B., Glaser S., Schaper C. [Association Between Serum Testosterone and Sex Hormone-Binding Globulin and Exercise Capacity in Men: Results of the Study of Health in Pomerania (SHIP)]. Journal of Andrology, 2011, vol. 32, pp. 135-143.

9. Koehler K., Parr M.K., Geyer H., Mester J., Schanzer W. [Serum Testosterone and Urinary Excretion of Steroid Hormone Metabolites after Administration of a High-Dose Zinc Supplement]. European Journal of Clinical Nutrition, 2009, vol. 63, pp. 65-70.

10. Kuhn C.M. [Anabolic Steroids]. Recent Progress in Hormone Resarch 2002, vol. 57, pp. 411-434.

11. Kumagai H., Zempo-Miyaki A., Yoshikawa T., Tsujimoto T., Tanaka K., Maeda S. [Increased Physical Activity Has a Greater Effect than Reduced Energy Intake on Lifestyle Modification-Induced Increases in Testosterone]. Journal of Clinical Biochemistry and Nutrition, 2016, vol. 58, no. 1, pp. 84 .

12. Kurt D., Denli O., Kanay Z., Güzel C., Ceylan K. [An Investigation of the $\mathrm{Cu}, \mathrm{Zn}$, and $\mathrm{Se}$ Levels of Blood Serum and the $\mathrm{Cu}$ and $\mathrm{Zn}$ Levels of Wool of Akkaraman Ewes in the Diyarbakir 


\title{
Спортивная тренировка
}

Region. Turkish]. Journal of Veterinary and Animal Sciences, 2001, vol. 25, pp. 431-436.

13. Moradi F. [Changes of Serum Adiponectin and Testosterone Concentrations Following Twelve Weeks Resistance Training in Obese Young Men]. Asian Journal of Sports Medicine, 2015, vol. 6, no. 4.

14. Morley J.E. [Testosterone and Behavior]. Clin Geriatr Med, 2003, vol. 19, pp. 605-616.

15. Neek L.S., Gaeini A.A., Choobineh S. [Effect of Zinc and Selenium Supplementation on Serum Testosterone and Plasma Lactate in Cyclist after an Exhaustive Exercise Bout]. Biol Trace Elem Res, 2011, vol. 144, pp. 454-462.

16. Ronsen O., Huge E., Klarlund P.B., Bahr R. [Increased Neuroendocrine Response to a Repeated Bout of Endurance Exercise]. Med Sci Sports Exerc, 2001, vol. 33, no. 4, pp. 568-575.

17. Seidman S.N. [Testosterone Deficiency and Mood in Aging Men: Pathogenic and Therapeutic Interactions]. World $J$ Biol Psychiatry, 2003, vol. 4, pp. 14-20.

18. Semba R.D. Nutrition and Health: Handbook of Nutrition and Ophthalmology. Humana Press Inc., Totowa, 2007, $496 \mathrm{p}$.

19. Simpson M., Xu Z. [Increased Abundance of Labile Intracellular Zinc During Cell Proliferation Was Due to Increased Retention of
Extracellular Zinc in $3 \mathrm{~T} 3$ cells], Journal of Nutritional Biochemistry, 2006, vol. 17, pp. 541-547.

20. Stoffel-Wagner B. [Neurosteroid Metabolism in the Human Brain]. Eur J Endocrinol, 2001, vol. 145, pp. 669-679.

21. Tuna Z., Güzel N.A., Aral A.L., Elbeg Ş., Özer Ç, Örer G.E., Pınar L. [Effects of an Acute Exercise Up to Anaerobic Threshold on Serum Anabolic and Catabolic Factors in Trained and Sedentary Young Males]. Gazi Medical Journal, 2014, vol. 25, no. 2, pp. 48-51.

22. Vingren J.L., Kraemer W.J., Hatfield D.L., Volek J.S., Ratamess N.A., Anderson J.M., Häkkinen K., Ahtiainen J., Fragala M.S., Thomas G.A., Ho J.Y., Maresh C.M. [Effect of Resistance Exercise on Muscle Steroid Receptor Protein Content in Strength-Trained Men and Women]. Steroids, 2009, vol. 74, no. 13-14, pp. 1033-1039.

23. Zarrouf F.A., Artz S., Griffith J., Sirbu C., Kommor M. [Testosterone and Depression: Systematic Review and Meta-Analysis]. $J$ Psychiatr Pract, 2009, vol. 15, pp. 289-305.

24. Zulkarnain Satria D., Yus T.M., Rezeki S. [Effects of Regular Physical Exercise on Blood Glucose Levels and Its Relationship to Total Testosterone Levels in Diabetic Rats]. Majalah Kedokteran Bandung, 2015, vol. 47, no. 1, pp. 16-21.

Received 17 November 2017

УдК 796.015 + 613.2:669.5

DOI: $10.14529 / \mathrm{hsm} 170407$

\section{ВЛИЯНИЕ ПОТРЕБЛЕНИЯ ЦИНКА И СИЛОВЫХ ТРЕНИРОВОК НА УРОВЕНЬ ТЕСТОСТЕРОНА}

\author{
В. Чунар ${ }^{1}$, Л.Г. Талагир ${ }^{2}$, Т. Акбулут ${ }^{1}$, М. Тургут $^{3}$, М. Сарукайя $^{4}$ \\ ${ }^{1}$ Фиратский университет, г. Элязыг, Турция; \\ ${ }^{2}$ Нижнедунайский университет, г. Галац, Румыния; \\ ${ }^{3}$ Бартынский университет, г. Бартын, Турция; \\ ${ }^{4}$ Университет Ван Юзунджул, г. Ван, Турция
}

Цель. Целью настоящего исследования являлось изучение того, как потребление цинка в сочетании с силовыми тренировками влияет на уровень тестостерона у людей, ведущих малоподвижный образ жизни, и у спортсменов. Материалы и методы. В исследовании приняли участие 40 мужчин, 20 из которых вели малоподвижный образ жизни и 20 регулярно занимались физической активностью. Участники были поделены на 4 равные группы, а именно: группа 1 - контрольная группа (S); группа 2 - участники, ведущие малоподвижный образ жизни и получающие добавку с содержанием цинка (Z); группа 3 группа спортсменов, занимающихся силовыми тренировками и получающих добавку с содержанием цинка (ZT); группа 4 - группа спортсменов, занимающихся силовыми трени- 
ровками (Т). Уровень общего тестостерона и несвязанного тестостерона измерялся в образцах крови, взятых у участников в начале исследования и шесть недель спустя. Результаты. Было установлено, что уровень общего и несвязанного тестостерона возрос в группах, которые получали добавку с содержанием цинка и занимались силовыми тренировками, в зависимости от потребления цинка и особенностей тренировки. Выводы. Потребление добавки с содержанием цинка и силовые тренировки на протяжении шести недель ведут к повышению уровня тестостерона, что, соответственно, оказывает положительный эффект на результативность.

Ключевые слова: упражнения, потребление цинка, тестостерон.

Чунар Ведат, профессор, доктор наук, факультет спортивной науки, кафедра физической культуры и спорта, Фиратский университет, г. Элязыг, Турция. E-mail: cinarvedat@hotmail.com.

Талагир Лаурентиу-Габриэль, профессор, доктор наук, факультет физической культуры и спорта, кафедра одиночных видов спорта и кинезитерапии, Нижнедунайский университет, г. Галац, Румыния. E-mail: gtalaghir@ugal.ro.

Акбулут Танер, младший научный сотрудник, факультет спортивной науки, кафедра физической культуры и спорта, Фиратский университет, г. Элязыг, Турция. E-mail: akbuluttaner23@ gmail.com.

Тургут Мине, младший научный сотрудник, Школа физической культуры и спорта, кафедра физической культуры и спорта, Бартынский университет, г. Бартын, Турция. E-mail: minetrgt@ gmail.com.

Сарукайя Мюджахит, младший научный сотрудник, Школа физической культуры и спорта, кафедра физической культуры и спорта, Университет Ван Юзунджул, г. Ван, Турция. E-mail: mucahit.sarikaya@hotmail.com.

Поступила в редакцию 17 ноября 20172.

\section{ОБРАЗЕЦ ЦИТИРОВАНИЯ}

The Effects of the Zinc Supplementation and Weight Trainings on the Testosterone Levels / V. Cinar, L.G. Talaghir, T. Akbulut et al. // Человек. Спорт. Медицина. 2017. - T. 17, № 4. - C. 58-63. DOI: 10.14529/hsm170407

\section{FOR CITATION}

Çınar V., Talaghir L.G., Akbulut T., Turgut M., Sarkaya M. The Effects of the Zinc Supplementation and Weight Trainings on the Testosterone Levels. Human. Sport. Medicine, 2017, vol. 17, no. 4, pp. 58-63. DOI: $10.14529 / \mathrm{hsm} 170407$ 